dont la publication a été recommandée par la CCTA/CSA; la protection des antiquités et des sites préhistoriques tchadiens; l'exploitation méthodique d'un gisement de la période SAO II, d'ores et déjà sondé au cours d'un séjour précédent; la réunion de collections archéologiques et ethnographiques destinées au Musée tchadien dans lequel seront également rassemblés les manuscrits et les rapports intéressant l'histoire des populations de la République; l'établissement d'un programme rationnel de recherches archéologiques, historiques et ethnologiques pour l'ensemble du territoire de la République afin que les représentants de ces diverses disciplines puissent désormais travailler en liaison les uns avec les autres.

La Mission, à laquelle se joindra pendant le mois de février r960 le Docteur Tchékoff, Médecin des Hôpitaux, compte séjourner plusieurs mois dans la République du Tchad et entreprendre également une prospection dans le nord du Cameroun.

[Communicated by M. Jean-Paul Lebeuf]

\title{
The Second Annual Meeting of the African Studies Association
}

The second annual meeting of the African Studies Association was held at Boston University from 7-9 September 1959 and was attended by over 300 scholars, under the presidency of Professor Gwendolen M. Carter.

The general subject of the meeting was political, social, and economic changes in Africa, and papers were read and discussed on: Fragmentation and Consolidation in Sub-Saharan Africa; The Role of Incentives in African Change; Conflict and Control in African Social Systems; The Arts and Humanities; Economic Development in Africa; Geographic Field Research in Africa; The Study of African History; and Political Science and African Studies. There was also a discussion on career and training opportunities for the African specialist, in which Mr. Alan Pifer, Professor Melville J. Herskovits, Dean Robert C. Parsons, Mr. Hyde Buller, and Mr. Melville Fox were the speakers. Mr. Fox made the point that government had relatively little appreciation of the usefulness of the trained African specialist and that it was not geared to make direct use of the trained scholar. A complete survey of supply and demand for African specialists was needed, and the African specialist in government and the private scholar should become more aware of one another.

\section{Royal Charter Presented to Fourah Bay College}

UNrversities and University Colleges in Britain and East, West, Central, and North Africa were represented at the formal presentation of the Royal Charter conferring University College status on Fourah Bay College on 28 January 1960. The presentation was made by the Governor, Sit Maurice Dorman, on behalf of the Queen, who is Visitor of the University College, and to Mr. Justice S. B. Jones, Vice-President of the University College Council. Fourah Bay College was founded by the Church Missionary Society, and has for many years been associated with Durham University, which was represented at the ceremony by Professor G. H. J. Daysh, sub-Rector of King's College, Newcastle.

\section{Margaret Wrong Memorial Fund: Award for 1959}

The Margaret Wrong Prize and Medal for 1959 has been awarded to Mr. Chinua Achebe, of the Eastern Region Nigeria Broadcasting Corporation, for his first novel, Things Fall Apart, published by Messrs. William Heinemann. The novel deals with Ibo village life at the first impact of missionary influence and British administration in Eastern Nigeria. 